創薬プロジェクトへの新しいハイスループットシステム一分子ディスプレイと コンビナトリアル・バイオエンジニアリングの集積·共役

植田充美

\title{
Novel High-Throughput System for Production of New Medicines-Integration and Combination with Molecular Display and Combinatorial Bioengineering
}

\author{
Mitsuyoshi UEDA \\ Division of Applied Life Sciences, Graduate School of Agriculture, Kyoto University, \\ Kitashirakawa-oiwake-cho, Sakyo-ku, Kyoto 606-8502, Japan
}

(Received June 17, 2009)

\begin{abstract}
To demonstrate the practical use of a novel high-throughput screening system by single cells constructed by the molecular display method, a yeast cell chip microchamber array was developed. As applications, peptides, peptidases, and antibodies were examined. Neurolysin originally recognizes substrates with six-amino-acid-long residues, cleaving a peptide bond in the center position of the substrate amino acid sequence. To alter the recognition of the P2' amino acid of substrates by neurolysin, six residues of neurolysin which might be involved in the formation of the neurolysin S2' subsite were individually and comprehensively substituted by semirational mutagenesis coupled with the yeast molecular display system. The protein libraries of mutant neurolysins were displayed on the yeast cell surface and screening was carried out using two fluorescence-quenching peptides, the matrix metalloproteinase-2/9- and MMP-3-specific substrates. Among mutant neurolysins, one mutant neurolysin with a marked change in substrate specificity was successfully obtained. Furthermore, skillful display of antibodies ( $\mathrm{H}$ and $\mathrm{L}$ chains) on the cell surface of yeast cells suggested the possibility of new approach for the creation of tailor-made proteases beyond limitations of the traditional immunization approach. Accordingly, the combination of the molecular display and combinatorial bioengineering would lead to produce novel medicines.
\end{abstract}

Key words_-molecular display; high-throughput screening system; cell surface engineering; cell chip

\section{1. はじめに}

近年医療分野において，タンパク質医薬品（生理 活性ペプチド・抗体・ホルモン・血液因子・成長因 子・インターフェロン）が注目されている. タンパ ク質医薬品は生体内において対象とする生理現象を 制御することで病状の改善を図るものであり，主要 なものとして，抗体やペプチドがある。ペプチドは 生体内で生理活性ペプチドとしても働き，生理現象 におけるシグナル伝達をも増強するものが存在す る.一般に生理活性ペプチドは対応するペプチダー ゼに分解されて不活性化されることから，ペプチ ダーゼもペプチドの生理活性を制御する能力を持つ

京都大学大学院農学研究科応用生命科学専攻（T6068502 京都市左京区北白川追分町)

e-mail: miueda@kais.kyoto-u.ac.jp

本総説は, 日本薬学会第 129 年会シンポジウム S05 で

発表したものを中心に記述したものである.
タンパク質医薬品分子として有用である。ペプチ ダーゼや抗体をタンパク質医薬品として使用するに は，副作用の低減のためにも高い基質特異性を持っ ていることが重要である. しかしながら, 数の限ら れている既存のペプチダーゼの中から目的のペプチ ドを認識する高い特異性を持つものを探索すること は困難である。そこで，高い基質特異性を持つペプ チダーゼや逆に，多様性を持つ抗体を人工的に効率 よく創出する方法として，分子ディスプレイ法を用 いた機能改変はその 1 つとして期待される。

ゲノム情報をタンパク質に変換していくタンパク 質調製系として，多くの遺伝子に由来するタンパク 質を網羅的に，最少量，かつ迅速に（これは，ハイ スループットとも呼ばれる）選択して機能解析する には，導入した個々のDNA から生まれてきた個々 のタンパク質を個々の細胞の表層や細胞膜などの上 に安定な形で提示（分子ディスプレイ）すると，分 
子ディスプレイされた細胞を 1 つの支持体として, 分子ディスプレイされたタンパク質をいつも生きた まま，必要ならいつでも増幅できるなど，その活性 や機能解析が容易となる．さらに，タンパク質のア ミノ酸配列分析をしなくても，PCR（遺伝子増幅） 法などの併用により，導入された DNA の配列から 分子ディスプレイされたタンパク質のアミノ酸配列 が決定できるというほかの方法論の追随を許さな い, 次世代シークエンシング時代に適応したメリッ トも創出される。こう言つたゲノム情報分子をタン パク質機能分子に変換する新しく，簡易で，迅速 で，しかも，多くの組み合わせの（コンビナトリア ル）分子ライブラリーから適合するものをシステマ ティックに選択することのできる手法として登場し てきたのが，ニューバイオテクノロジーとしての 「コンビナトリアル・バイオエンジニアリング」手 法である. ${ }^{1,2)}$

2. 分子ディスプレイ：アーミング技術による夕 ンパク質機能検索のハイスループット化

われわれは，酵母の細胞表層への分子ディスプレ イ法一酵母の細胞表層工学一という新しいバイオテ クノロジー分野を開拓してきた (Fig. 1). 1-4) 1999 年ノーベル医学生理学賞を受賞した Blobel 教授の 「タンパク質におけるシグナル説」で周知のごとく, 細胞内のすべてのタンパク質は，個々に固有の「ア ドレス」を指定する情報を持ち，その情報に基づい て輸送され局在化し，そこで機能を発揮している. 酵母を用いた分子ディスプレイでは，細胞表層で機

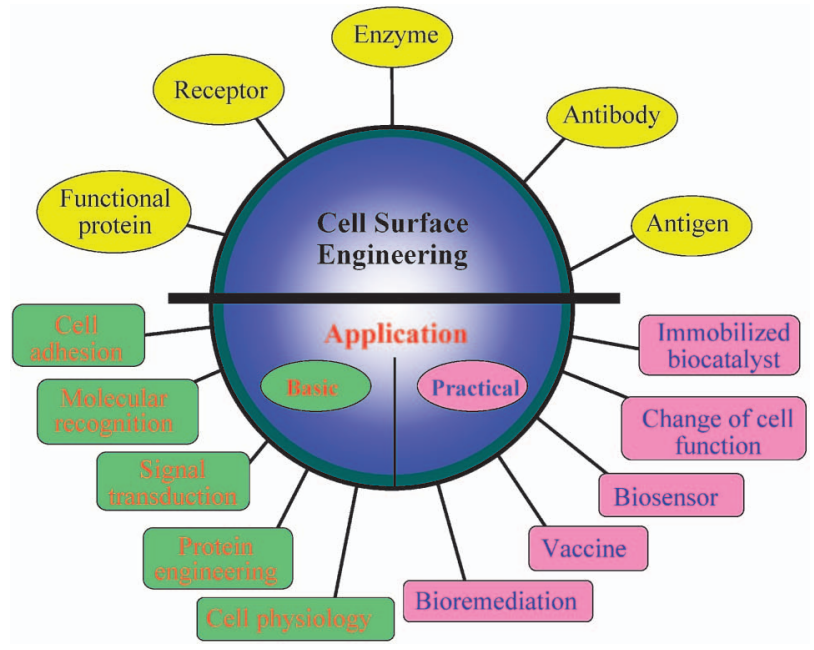

Fig. 1. Cell Surface Engineering and Its Application
能を発揮しているタンパク質の「アドレス」を指定 する遺伝子情報を用いた機能タンパク質の新しい発 現手法として，【細胞表層工学（Cell Surface Engineering)】を考案した。最も単純でヒトの生活に 既に密接に係わっている真核細胞であるパン酵母 Saccharomyces cerevisiaeを用いた場合，この細胞

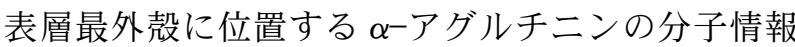
を活用することによって種々の酵素やタンパク質を 細胞表層にディスプレイすることが可能となってき

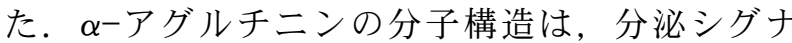
ル・機能ドメイン・細胞壁ドメイン（セリンとスレ オニンに富む $\mathrm{C}$ 末 320 アミノ酸残基）からなって おり，この $\mathrm{C}$ 末 320 アミノ酸残基の $\mathrm{C}$ 末端に GPI アンカー付着シグナルが存在する.したがって，こ の分泌シグナルと機能ドメインを操作することによ って，これまでに，異種由来の酵素や各種因子や受 容体など分子サイズの大きいタンパク質を，単独 で，あるいは，協奏的に細胞表層に発現提示させる ことに成功し（Fig. 2)，酵母がこれまで持たなか つた機能を持った新機能酵母を創製してきた. ${ }^{1-4}$ このような細胞は，アメリカの Chemical \& Engineering News [Vol. 75, p. 32 (1997)]でもいち早 く取り上げられ，「アーミング酵母 (Arming Yeast)」 と命名されており，こう言つた技術は「アーミング 技術」として，ニューバイオテクノロジーを支える 基盤技術となってきている。

3. 高速で簡便な網羅的タンパク質ライブラリー の作製

これまで，例えば，タンパク質の機能の解析に は，目的とするタンパク質をコードする遺伝子を単 離し，過剩発現する系を構築し，大量調製したその タンパク質を結晶化し，X-線構造解析を行い，そ のモデリングからランダム変異法や，特に，部位特 異的変異法を用いて，構造と機能の相関を明らかに したり，機能改善したりする研究が主流であった. こころが，ここで登場してきた細胞表層分子ディス プレイを基幹とする「コンビナトリアル・バイオエ ンジニアリング」技術により，これまでの「点での 変異」による戦略から，「コンビナトリアルな変異」 という狙ったアミノ酸残基やドメインを 20 種のア ミノ酸で網羅的に変異をかけたタンパク質集団を作 製し，そこから目的のものを直接的にハイスループ ットに選択して解析する戦略が可能となったのであ 


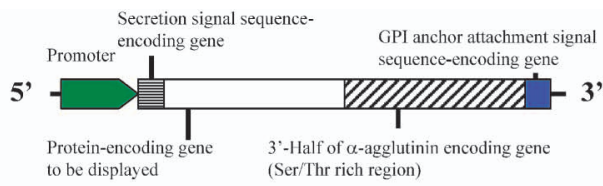

Molecular design of the fusion gene for cell-surface display

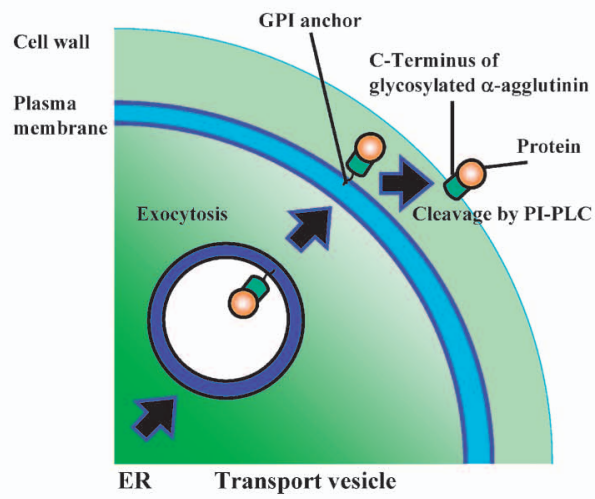

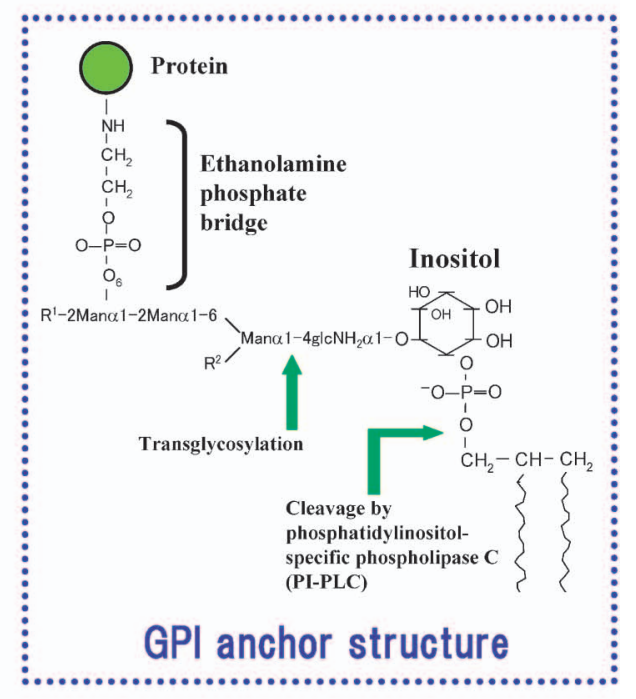

Transportation mechanism of the foreign protein to the cell wall

Fig. 2. Mechanism of Cell Surface Engineering (Molecular Display)

る．酵母の場合，導入した遺伝子型とその発現され た表現型が対応関係になっているので，導入したプ ラスミドの挿入部位近傍のプライマーを用意してお くだけで，ディスプレイした，例えば，変異タンパ ク質の分子配列を DNA 配列分析から決定できる. また，それぞれのコンビナトリアルな変異タンパク 質を個々に煩雑な精製をする必要なく，細胞ごと変 異タンパク質として扱え，まさに，タンパク質に増 殖性と保存性を持たせた革命的な方法論を提供する ものである．この手法は，特に，タンパク質の機能 評価や SNPs 対応タンパク質（一塩基変異に起因す る）の活性評価（ポスト SNPs 研究）において (Fig. 3)，革新的な，あるいは，ブレークスルー的 手法となり，まさにタンパク質機能解析への真の新 しい視点を提供することになるであろう.5)

\section{4. ペプチド}

モデルとして，ラット脳由来のメタロペプチダー ゼであるニューロライシン（EC3.4.24.16）を用い た。ニューロライシンの基質は血管作用性生理活性 ペプチドであるニューロテンシンが有名であるが, 特異性については不明な点が多い。そこで，最初に 野生型ニューロライシンの基質特異性を調査するた めに，ニューロライシンを酵母の細胞表層にディス プレイして調査したところ，野生型ニューロライシ ンは 2 種類の認識モチーフを持つことが明らかにな
つた.このモチーフに当てはまる生理活性ペプチド を検索したところ，摂食行動の制御に係わる Orexin B, Neuromedin B, Urocortin の3つのペプチドを 同定できた。このことから，ニューロライシンは生 体内において，摂食行動の制御に係わることも示唆 された. ${ }^{6)}$ 一方，ニューロライシンはがんの浸潤・ 転移に関与するマトリックスメタロプロテアーゼ-2 あるいはマトリックスメタロプロテアーゼ-9(以下， MMP-2/9）に特異的な基質を効率よく切断するこ とが分かった。結晶構造を比較すると，ニューロラ イシンは，MMP 群の活性ドメインと同じ 3-Layer Sandwich 構造を持ち，MMP-2/9 とよく似た基質 特異性を持つことが明らかになり，また，基質認識 に重要ないくつかの残基を推定することができ た。7また，MMP-2/9 を特異的に阻害する活性阻 害剤はニューロライシンの活性も効果的に阻害する ことが明らかになり，ニューロライシンをディスプ レイした酵母を用いて抗がん剂となる MMP-2/9 阻害剂の網羅的スクリーニングによる評価ができる ことも分かった.

ところで，野生型ニューロライシンは MMP-2/9 特異的ペプチドを効率よく切断するが， MMP-3 特 異的ペプチドに対してはあまり活性を示さない。こ れらのペプチド配列はほとんど同じだが，P1'と P2’ 部位のアミノ酸が異なる（MMP2/9 特異的ペ 


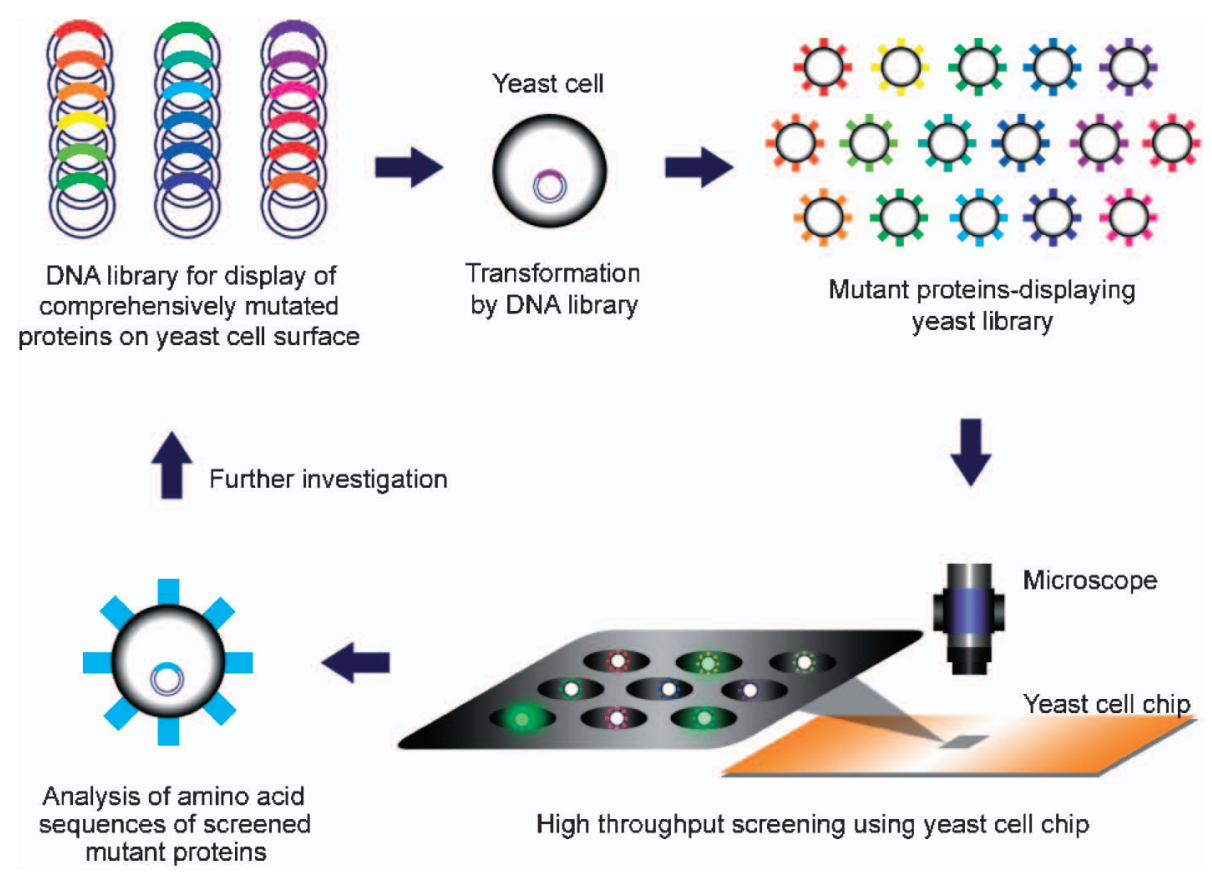

Fig. 3. Screening System for Target Cells and Proteins by the High-Throughput Method Coupled with Molecular Display and Yeast Cell Chip

プチドの P1’はチロシン, P2’ はアラニンだが, MMP-3 特異的ペプチドではそれぞれバリンとグル タミン酸)。そこで，ニューロライシンが MMP-3 に特異的なぺプチドを切断するように改変タンパク 質を作成するために，既存の基質認識残基の情報 と, よく似た基質特異性を持つ $\mathrm{MMP}-2 / 9$ との構 造比較により, $\mathrm{P} 1$ ’ と $\mathrm{P} 2$ ’ 部位の認識残基を推定し て 6 つの残基を選び，それぞれを網羅的にほかの 19 種類のアミノ酸に置換した合計 120 種類からな る変異体ライブラリーを作製した。このライブラ リーの中から MMP-3 に対する活性が高い変異体 をスクリーニングしたところ，アルギニン 470 ある いはチロシン 610 に変異が導入された変異型ニュー ロライシンが得られた。最も特異性が変化した Y610L 変異体については, 反応速度論的解析を行 うとともに，その解析を基にして基質認識ポケット の構造変化を予測した。このように，分子ディスプ レイ法を利用して，望む特異性を持つペプチダーゼ を迅速に創出することもできた. ${ }^{8)}$

\section{5. 抗体分子の創出}

分子ディスプレイの高速な改変タンパク質創出性 を利用して，哺乳類の免疫系を使うことなしに試験 管内で迅速に抗体酵素の作成あるいは機能解析に, 実際にこのシステムを用いて，モデル抗体酵素を創
出し解析した例について述べる.

近年, 病巣特異的なドラッグデリバリーシステム を実現するために，プロドラッグ（薬となる物質の 安定な前駆体化合物）を投与し，病巣で酵素的に活 性化して機能させることが試みられている。この方 法でポイントになってくるのは，病巣以外で活性化 されないようにプロドラッグを設計することと，プ ロドラッグを活性化する酵素が病巣に存在すること である。しかし，活性化に都合のよい酵素が存在す ることはほとんどなく，高いプロドラッグ特異性と 望ましい触媒活性を持つ酵素を人工的に作成して用 いる必要がある。そこで触媒活性を持つ抗体（抗体 酵素あるいは触媒抗体と呼ばれる）が注目されてい る．抗体酵素は化学反応を触媒する抗体であり，酵 素と同様に反応の遷移状態と結合して安定化するこ とで触媒能力を持つ。構造は通常の抗体と同じなの で可変領域の多様性によって高い基質特異性を持つ ものが得られやすい半面，望ましい触媒活性を持つ ように変異体を作成しても活性が弱いことが多い， そのためハプテンの設計を工夫したり，ファージデ イスプレイシステムによってより高い活性を持つ変 異型抗体を作成したりすることが必要になる.

本来，抗体酵素とは人工的に作られたものを指し ていたが，ヒトの体内でも特定の疾患の原因分子と 
していくつか見い出されてきている，例えば血管作 動性小腸ペプチド（VIP: Vasoactive Intestinal Peptide）を特異的に分解する抗体酵素9)（VIPase と呼 ばれる）やDNA に結合して分解する抗体酵素10) が，それぞれ喘息患者あるいは全身性エリテマトー デス患者から発見されている。これらの場合は治療 薬のターゲット分子として重要である.

通常，人工的に抗体酵素を作るには哺乳類の免疫 系を利用し，目的とする反応の遷移状態を模した物 質（遷移状態アナログ）を投与してこの遷移状態ア ナログに結合する抗体を作らせる，しかし，この作 成方法では抗体ができるまでに数力月かかる上に血 清からモノクローナル抗体を精製する必要があり時 間と手間がかかる。アミノ酸配列の決定，酵素活性 の測定，基質特異性の解析などはさらに大変であ る。そのため，上記の問題点を一掃できる酵母分子 ディスプレイシステムを抗体酵素の作成と機能解析 に利用してきている.

実際に抗体分子の Fab (Antigen Binding Fragment) 断片を酵母細胞表層にディスプレイすることを試み た。 Fab 断片は「軽鎖」と「Fd 断片（重鎖の定常 領域と可変領域で構成される)」の 2 つのサブユニ ットがジスルフィド結合でつながっているへテロダ イマーであり，全長の抗体分子と同様に抗原結合能 を持つ，そこで，それぞれを別々のべクターに組み 込んで軽鎖と Fd 断片を生産させることにした
(Fig. 4). 軽鎖をディスプレイするために，分泌シ グナルをコードする遺伝子，軽鎖をコードする遺伝 子， $\alpha$-アグルチニンの細胞壁ドメインをコードす る遺伝子をこの順に融合させた。これを酵母内で発 現させると軽鎖と $\alpha$-アグルチニンの融合タンパク 質は分泌シグナルによって細胞表層へ輸送され，表 層最外殼に固定化される。一方， $\mathrm{Fd}$ 断片の遺伝子 も同じ分泌シグナルの下流に置かれ，これを発現さ せると軽鎖と同じ経路で細胞表層へ輸送される。こ れら 2 つのベクターを酵母の染色体に組み込んで発 現させたところ，軽鎖と Fd 断片は細胞表層に輸送 される過程でジスルフィド結合を形成し，Fabとし て酵母の細胞表層にディスプレイされ，抗原への結

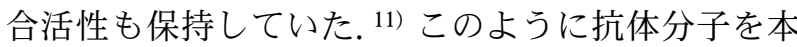
来の活性を保った状態で酵母の細胞表層へディスプ レイできたことにより，哺乳類の免疫系に依存せず に酵母の細胞表層，すなわち試験管内で抗体を作成 することが可能になった。

試験管内で，酵母ディスプレイシステムを用いる 場合には抗体ライブラリーの中から反応速度を指標 に活性が高い抗体を細胞のまま直接スクリーニング することが可能であり，アミノ酸配列は対応する DNA 配列を調べることで容易に決定できる。この 時に使用する抗体ライブラリーも，抗体分子をコー ドする遺伝子をライブラリー化するだけでよいの で，生体内と同じように可変領域がランダムになつ
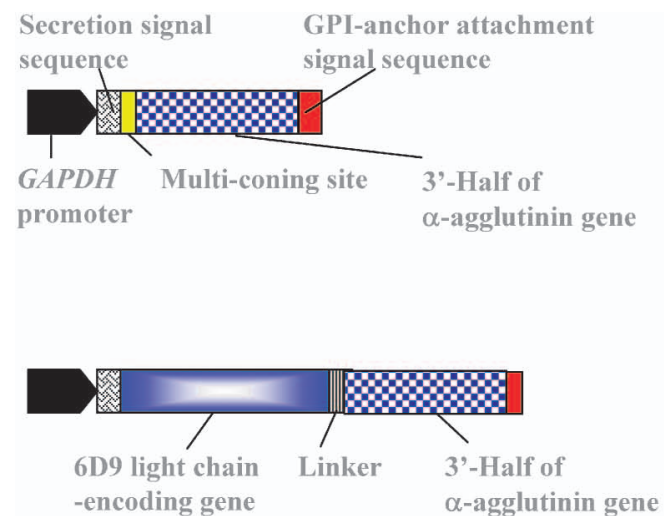

TSA-conjugated FITC
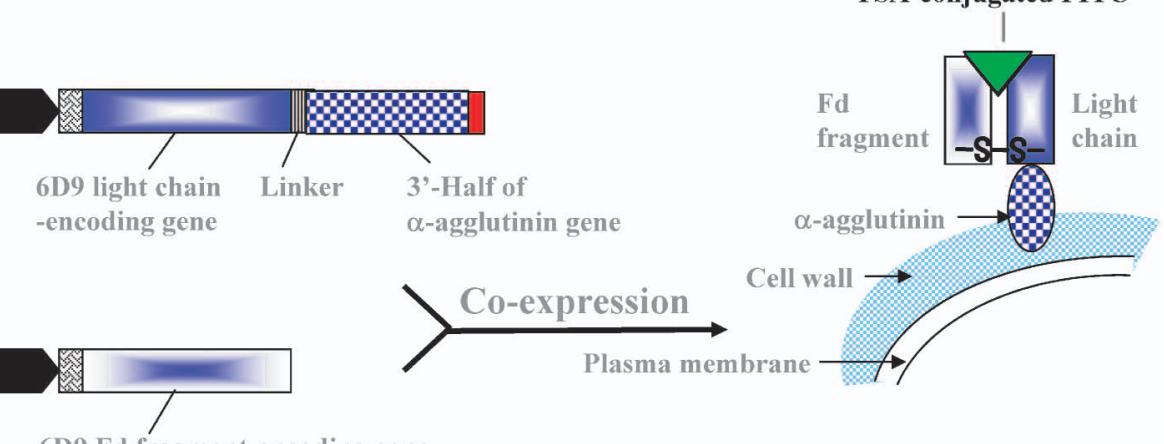

$6 \mathrm{D} 9 \mathrm{Fd}$ fragment-encoding gene

Fig. 4. Illustration of Display of Fab Fragment on the Cell Surface of the Yeast Cell 
ているものを始め，定常領域をランダム化したも の，アミノ酸を挿入・欠損させたものなど自由に設 計できる。このことは抗体ライブラリーの多様性を 非常に大きくすることが人為的に自由にできること を意味しており，哺乳類の免疫系ではアポトーシス により消滅させられる抗体や作成不可能な抗体や抗 体酵素などが取得できるような抗体の多様性を実現 できる可能性が高いと考えられる。

喘息患者の血清から発見された抗体酵素 VIPase ${ }^{9)}$ のように，プロテアーゼ活性を持つ抗体酵素につい

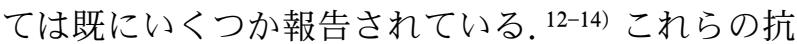
体酵素においては，軽鎖中の 3 つの残基 Asp1， Ser27a, His93 が触媒トライアードを形成すると考 えられている，触媒トライアードは加水分解酵素に 多くみられる触媒中心を形成する構造モチーフであ り，プロテアーゼにおいてはセリンプロテアーゼに よくみられる，そこでこれらの知見を基に，部位特 異的変異法によって触媒トライアードを導入した軽 鎖を酵母細胞表層にディスプレイし，迅速に簡便に プロテアーゼ機能の解析を行った。 モデル抗体とし て，もともとプロテアーゼ活性を持たない抗体軽鎖 断片を用いた．プロモーターの下流に分泌シグナル

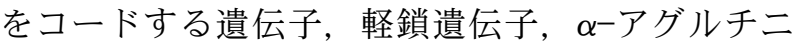
ンの細胞壁ドメインをコードする遺伝子をこの順に 組み込み，軽鎖を細胞表層へディスプレイするべク ターを構築した（野生型軽鎖）。軽鎖断片にプロテ アーゼ活性を付与するために，構築した軽鎖（野生 型軽鎖)をディスプレイするベクターを鋳型にして, Asp1, Ser27a, His93 となるように部位特異的変異 法により変異を導入した（変異型軽鎖）。これらの ベクターを宿主酵母に導入して野生型軽鎖及び変異 型軽鎖を細胞表層へディスプレイした．作成した抗 体軽鎖ディスプレイ酵母 (野生型軽鎖，変異型軽鎖) のプロテアーゼ活性は非常に簡便に測定することが できた。具体的にはこれらの酵母を定常期まで培養 し，集菌と洗浄を行ったのちに，エッペンドルフチ ユーブ内で緩衝液に懸濁した。 そこに蛍光基質を加 えて反応を開始し， 24 時間後に反応液の上清の蛍 光強度を測定した。基質は様々なアミノ酸配列を持 つ 8 種類の蛍光ペプチドを使用した。 その結果，い くつかの蛍光ペプチド基質に対し変異型軽鎖ディス プレイ酵母は野生型軽鎖ディスプレイ酵母よりも高 い加水分解活性を示し, 特に, Suc-Gly-Pro-Leu-
Gly-Pro-MCA［Suc：スクシニル基，MCA：4-メ チルクマリル-7-アミド基（蛍光基）］に対する加水 分解活性は顕著に増加していた。この活性はセリン プロテアーゼ阻害剤である DFP（ジイソプロピル フルオロリン酸）を加えることで完全に消失した. つまり，変異型軽鎖はセリンプロテアーゼ型の活性 を示し，また Suc-Gly-Pro-Leu-Gly-Pro-MCA を特 異的に切断することからこの変異型軽鎖はコラゲ ナーゼのような基質特異性を持つことが示唆され

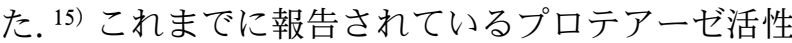
を持つ抗体酵素において，VIPase は Lys や Arg の C 末端側を好んで切断し, i41SL1-2-Lc は CDRL-1 という 16 残基からなるペプチドを Arg-Ser の間で 切断し, ${ }^{13)}$ ECL2B-2-Lc は CCR-5 という 22 残基か らなるぺプチドを Arg-Ser，Tyr-Ser，Phe-Trp，ThrLeu など複数の部位で非特異的に切断する. ${ }^{14)}$ 今回 作成した変異型軽鎖はどの抗体酵素とも違う基質特 異性を持ったことから，これらの軽鎖のアミノ酸残 基の種類の違い，立体構造の局所的な違いを比較し ていけば，軽鎖をべースとしたプロテアーゼ型抗体 酵素の基質特異性を決定しているメカニズムを明ら かにすることができるのではないかと期待できる.

実際に抗体ライブラリーからスクリーニングする 時にはスクリーニング手段が重要になってくるが, われわれは，現在，酵母細胞チップ（日本板硝子社 製）の開発も行っている（Fig. 5)。酵母細胞チッ

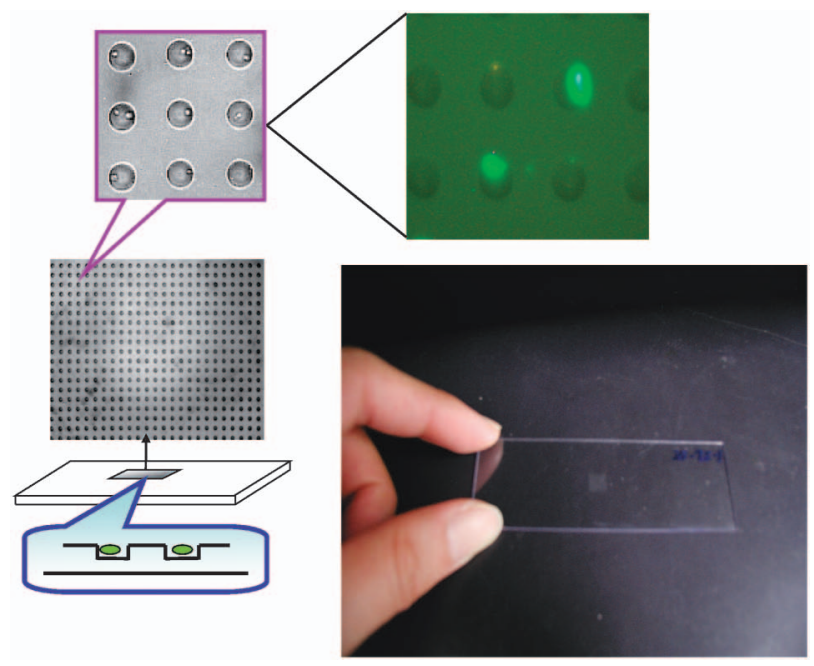

Fig. 5. Yeast Cell Chip and Its Application to Screen the Target Cell

The chip has $100 \times 100=10000$ microchambers (Nippon Itagarasu) on its face. One microchamber is $20 \mu \mathrm{m}$ diameter and $8 \mu \mathrm{m}$ depth. 


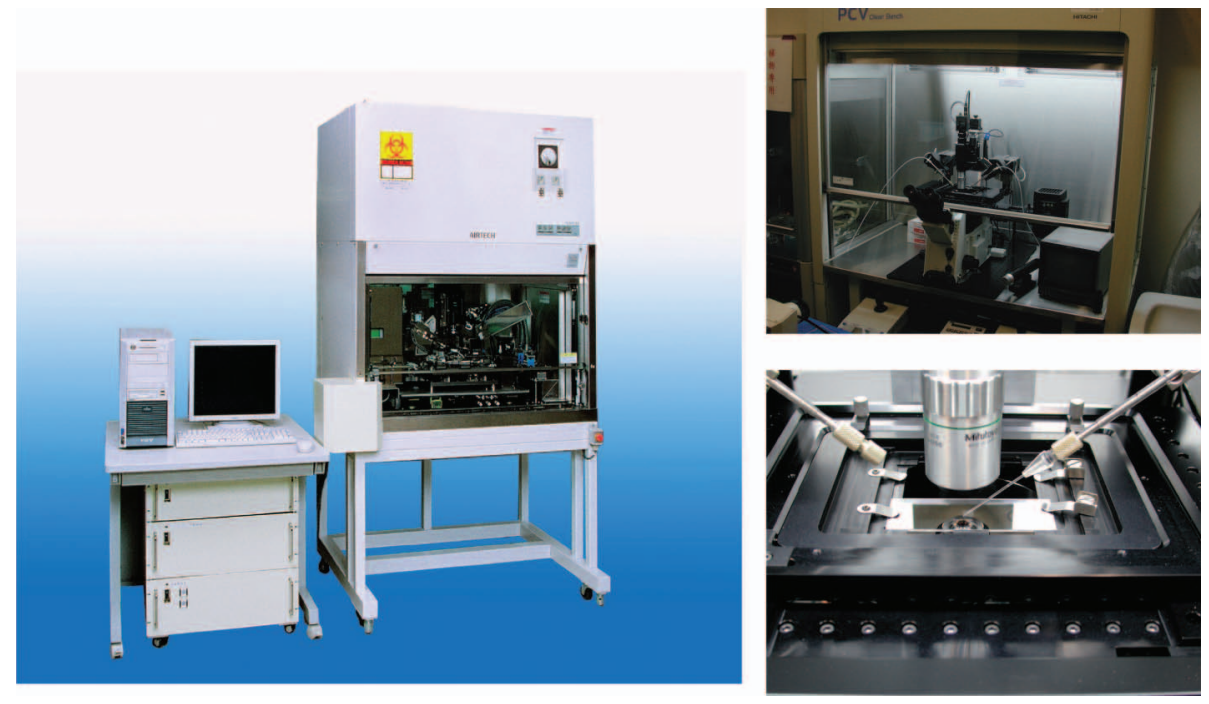

Fig. 6. Single Cell Picking-up Machine (Fujitsu)

プとは, 直径 $20 \mu \mathrm{m}$ 程度で深さ $8 \mu \mathrm{m}$ 程度のマイク ロチャンバーからなり，1 枚のチップ上に $100 \times 100$ $=10000$ 穴のマイクロチャンバーを有する.このチ ヤンバー内には 1-2 個の酵母細胞を浸漬することが でき，それぞれのチャンバー内で直接一細胞反応を 行い，それを顕微鏡で観察し，目的の酵母細胞をピ ックアップし，ダイレクト PCR 及びそれに続く DNA シーケンシングあるいは培養することができ る（Fig. 6，富士通社製，シングルセルピックアッ プ装置). ${ }^{16,17)}$ これは，1 枚の小さなチップ上にて従 来の膨大なスクリーニング作業を集積化できること を意味する，さらに，酵母細胞表層にディスプレイ された抗体は容易に回収もできる。すすおちち抗体と

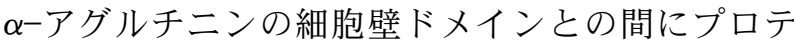
アーゼの認識配列を挿入しておけば，抗体がディス プレイされた酵母細胞を培養・集菌した後にプロテ アーゼを作用させることによって抗体だけを細胞表 層から切り出すことも可能である. ${ }^{18)}$ 今後, この開 発した酵母分子ディスプレイシステムと酵母細胞チ ップの共役システムにより，個体免疫系では作れな い有用な抗体や抗体酵素の創出と機能解析の展開が 期待できる.

以上のように，酵母分子ディスプレイを利用する ことで, タンパク質の機能の解析と改変設計や，さ らには，アゴニストゃアンタゴニストのスクリーニ ングなどを簡便に効率よく行えるようになってきて いる．将来的には様々なタンパク質を用途に合わせ て改変設計したタンパク質医薬品が創出され，次世
代医療に貢献できるであろう。また，現在，疾患や 薬の効果にみられる個人差の 1 つの要因として, SNPs（一塩基多型）から生じるタンパク質多型が 注目されている，われわれの方法を使えば，それぞ れの多型タンパク質を簡便に作成し，機能変化を調 査することで，個人に最適な治療法（オーダーメー ド医療）を提供することも可能になると期待してい る.

\section{REFERENCES}

1) Ueda M., Kondo A., "Kagaku Frontier," Vol. 9, Kagaku Dojin, Kyoto, 2003.

2) Ueda M., "Frontier of Combinatorial Bioengineering," CMC, Tokyo, 2004.

3) Ueda M., Bioscience and Industry, 55, 275278 (1997).

4) Ueda M., Kagaku To Seibutsu, 35, 525-532 (1997).

5) Ueda M., Bionics, 27, 31-35 (2007).

6) Kadonosono T., Kato M., Ueda M., Appl. Microbiol. Biotechnol., 75, 1353-1360 (2007).

7) Kadonosono T., Kato M., Ueda M., Appl. Microbiol. Biotechnol., 75, 1285-1291 (2007).

8) Kadonosono T., Kato M., Ueda M., Protein Eng. Des. Sel., 21, 507-513 (2008).

9) Paul S., Volle D. J., Beach C. M., Massey R. J., Science, 244, 1158-1162 (1989).

10) Gabibov A. G., Gololobov G. V., Makarevich O. I., Schourov D. V., Chernova E. A., Yadav R. P., Appl. Biochem. Biotechnol., 47, 293- 
302 (1994).

11) Lin Y., Tsumuraya T., Wakabayashi T., Shiraga S., Fujii I., Kondo A., Tanaka A., Ueda M., Appl. Microbiol. Biotechnol., 62, 226-232 (2003).

12) Gololobov G., Sun M., Paul S., Mol. Immunol., 36, 1215-1222 (1999).

13) Hifumi E., Kondo H., Mitsuda Y., Uda T., Biotechnol. Bioeng., 84, 485-493 (2003).

14) Mitsuda Y., Hifumi E., Tsuruhata K., Uda T., Biotechnol. Bioeng., 86, 217-225 (2004).

15) Okochi N., Kato M., Kadonosono T., Ueda
M., Appl. Microbiol. Biotechnol., 77, 597-603 (2007).

16) Fukuda T., Shiraga S., Kato M., Morita Y., Tamiya E., Hori T., Suye S., Ueda M., Nanobiotechnology, 1, 105-111 (2005).

17) Fukuda T., Shiraga S., Kato M., Suye S., Ueda M., Biotechnol. Prog., 22, 944-948 (2006)

18) Maeda H., Nagayama M., Kuroda K., Ueda M., Biosci. Biotechnol. Biochem., 73, 753-755 (2009) . 